\title{
SENSITIVITY OF BOOPHILUS MICROPLUS (ACARI: IXODIDAE) TO PYRETHROIDS AND ORGANOPHOSPHATE IN FARMSIN THE VALE DO PARAÍBA REGION, SÃO PAULO, BRAZIL
}

\section{M.C. Mendes ${ }^{1}$, J.R. Pereira², A.P. Prado³}

IInstituto Biológico, Centro de Pesquisa eDesenvolvimento deSanidadeA nimal, Av. Cons. Rodrigues Alves, 1252, CEP 04014-002, São Paulo, SP, Brasil.

\begin{abstract}
A study to evaluate the resistance of B. microplus to the active principles cypermethrin, deltamethrin and chlorpyriphos was performed together with the survey of the tick control practices used in 12 farms located in Vale do Paraíba Region, São Paulo, Brazil. Results obtained by the larval packet test (LPT) technique, adopted by FAO, showed established resistance to pyrethroids (cypermethrin 16.7\% sensitive, 8.3\% resistant level I and 75\% resistant level II; deltamethrin $25 \%$ / sensitive, 33.3\% resistant level II and $41.7 \%$ resistant level III) and emerging resistance to organophosphate compounds (chlorpiriphos $58.3 \%$ sensitive, $33.3 \%$ resistant level I and $8.4 \%$ resistant level II). The inquiry applied to the farmers showed that the combination of organophosphates and pyrethroids compounds products is the most commonly tick-killing compounds used in the region, followed by amitraz and macrocyclic lactones.
\end{abstract}

KEY WORDS: Boophilus microplus, resistance, pyrethroids, organophosphate.

\section{RESUMO}

SENSIBILIDADE DO BOOPHILUS MICROPLUS (ACARI: IXODIDAE) AOS PIRETRÓIDES E ORGAN OFOSFORADOSEM FAZENDASLOCALIZADASNA REGIÃO DO VALEDO PARAÍBA, SÃO PAULO, BRASIL. Foi real izada pesquisa da resistência do Boophilus microplus aos princípios ativoscipermetrina, del tametrinaeclorpi rifóse, concomitantemente, feito ol evantamento sobre as práticas adotadas no controle do carrapato em 12 propriedades local izadas na região do Vale do Paraíba, São Paulo, Brasil. Os resultados obtidos por meio da técnica LPT (Larval Packet Test), segundo a classificação adotada, mostraram que, para a cipermetrina, $16.7 \%$ das fazendas apresentaram populações classificadas como sensíveis; 8.3\% com resistência nível I e 75\% com resistência nível II. Para a deltametrina, $25 \%$ sensíveis; 33.3\% com resistência nível II e $41.7 \%$ com resistência nível III. Para o organofosforado clorpirifós 58.3\% mostraram-sesensíveis; 33.3\% com resistência nível I e $8.4 \%$ com resistência nível II. Os questionários aplicados aos produtores revelaram queos produtos à base daassociação deorganofosforados com piretróides são os mais usados na região, seguidos do amitraz elactonas macrocíclicas.

PALAVRAS-CHAVE: Boophilus microplus, resistência, piretróides, organofosforados.

\section{INTRODUCTION}

Parasitic infestation by ticks causes clinical and subclinical syndromes that impair the development of cattle herds, mainly in dairy production with substantial economics losses. The knowledgement on management practices; including the methods used on thetick control in theV aledo Paraíba Region is important for the implementation of parasitary control programs.
Resistance of Boophilus mi croplustopyrethroidsand organophosphatehasbeen reported in several countries (Beugnet; Chardonnet, 1995; Romero etal., 1997; Romero et al ., 1998; DaveY; George, 1998; Baxter; Backer, 1999; Crampton et al., 1999; Miller-Robert etal., 1999; Jamroz etal., 2000; BenAVIDES; Romero, 2000; GuerRero etal ., 2001; BIANCHI et al., 2003). Therearefew reportsontheresistance of ticks by means of the larval packet test MENDES; Veríssimo, 1999; Vieira-BresSAn etal., 1999; Mendes etal., 2001) in the Vale do Paraíba Region, Brazil.

²ólo Regional deDesenvolvimento Tecnológico dosA gronegócios do Valedo Paraíba, Pindamonhangaba, SP, Brasil . 3Universidade Estadual de Campinas, Campinas, SP, Brasil. 
Theobjective of the present study was to evaluate the sensitivity of B. microplus field strains collected from farms located in theVale do Paraíba Region for two pyrethroids and one organophosphate compound, as well as to access the tick-control methods most commonly employed in these farms.

\section{MATERIAL AND METHODS}

Thestudy wasperformed in 12 farmslocated in the

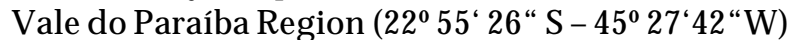
duringtwoyears. Informationontick control methods was gathered by a survey of thetick control practices adopted in twelve farms. The method used was the Larval Packet Test (StONE; HAYDOCK, 1962).

The following active principles (concentration given in parentheses) weretested:cypermethrin $(0.8 \%$, $0.4 \%, 0.25 \%, 0.1 \%, 0.05 \%$ and $0.0125 \%$ ), deltamethrin $(0.8 \%, 0.4 \%, 0.2 \%, 0.1 \%, 0.05 \%, 0.025 \%, 0.00625 \%)$ and chlorpyriphos $(0.4 \%, 0.2 \%, 0.1 \%, 0.05 \%, 0.025 \%$ and $0.0125 \%)$. The Mozo strain was used as the standard susceptibleto access resistance. Females of thetick B. microplus, collected in 12 farms werekept in a chamber at $27^{\circ} \mathrm{C}$ and relative humidity over $80 \%$. After 14 days, eggs were collected and transferred to a conic tube $(5 \mathrm{~mL})$ with a cotton lid to allow air and moisture exchange. After another 2 weeks the eggs were hatched and after a further 2 weeks the larvae were ready for testing. Samples with approximately 100 larvaeaging 14 to 21 days old wereremoved from the tube with the aid of a brush and placed in filter paper impregnated with thecompound to bestudied. After 24 hours, al iveand dead larvaewerecounted. In order to calculatelethal concentrations $50 \%$ and $99 \%$ $\left(\mathrm{LC}_{50}\right.$ and $\left.\mathrm{LC}_{99}\right)$ was used the probit analysis in PoloPC software. Data were discarded when mortality ratesinthecontrol groupwereover $10 \%$. Testsshowing mortality ratesin thecontrol group between $5 \%$ to $10 \%$ were submitted to Abbott's formula (Аввотт, 1925). The Resistance Factor (RF) was obtained by the quotient between $\mathrm{LC}_{50}$ of the unknown individual progenies and $\mathrm{LC}_{50}$ obtained for the M ozo strain.

Table 1 - Level of resistance classification used in the present study for pyrethroids and organophosphate compounds.

\begin{tabular}{lll}
\hline Classification & $\begin{array}{c}\text { Pyrethroids } \\
\text { RF }\end{array}$ & $\begin{array}{c}\text { Organophosphate } \\
\text { RF }\end{array}$ \\
\hline Sensitive & $\leq 2.4$ & $<1.4$ \\
Resistant level I & $2.5-5.4$ & $1.5-4.4$ \\
Resistant level II & $5.5-50$ & $4.5-50$ \\
Resistant level III & $>50$ & $>50$ \\
\hline
\end{tabular}

The system for the classification of resistance for pyrethroids and organophosphates compounds was based on the model presented by BIANCHI et al., (2003), with some changes in the values that determine tick sensitivity of ticks and in the expressions used by the authors to classify samples as sensitive or resistant. Two classifications were considered becausetherewas a greater degree of variation in the magnitude of the RF for pyrethroids and organophosphates compounds, (Table 1) (Barros, personal communication, 2004).

\section{RESULTS}

\section{Inquiry of Tick Control Practices}

From the 12 analyzed farms $72.7 \%$ were dedicated to milk production and $27.3 \%$ to both beef and dairy production. All of the had mixed breed cattle and performed acaricide treatments. The results for the products that had been used in the last five years and that were being used at the moment of the questionnaire were respectively, amitraz (38.1\% and $37.5 \%)$, association of organophosphate and pyrethroid $(23.8 \%$ and $43.7 \%)$, macrocyclic lactone ( $14.3 \%$ and $18.8 \%$ ). Regarding to application methods spray was the most common for tick control (67\%) followed by the injectable route (33\%).

\section{Resistance trials}

\section{Cipermethrin}

Mostof thetick populations (69.2\%) wereresistant level II for cypermethrin, with values ranging from 12.2 to 38.6. Resistant level I was only found in one farm (8.3\%) and $16.7 \%$ were classified as sensitive. Farm 10 ticks showed to bemoresensitivethan M ozo strain

\section{Deltamethrin}

Most of the samples analyzed for deltamethrin showed to be resistant level III (41.7\%) and resistant level II (33.3\%), the remaining were sensitive (25\%). Farm 10 ticks showed to be sensitive than Mozo strain.

\section{Chlorpyriphos}

Most of the tick population showed to be sensitive to chlorpyriphos (58.3\%), whereas the remaining was resistant level I (33.3\%) and level II (8.4\%). It was observed that farm 10 presented a RF similar to that of the M ozo strain, with $\mathrm{LC}_{50}$ equal to $0.016 \%$. 
Table 2 - Values for lethal concentrations 50\% ( $\left.\mathrm{LC}_{50}\right)$ and $99 \%\left(\mathrm{LC}_{99}\right)$ and their respective $95 \%$ confidencelimits for 12 Boophilus microplus population tested against the pyrethroid cypermethrin.

\begin{tabular}{|c|c|c|c|c|c|}
\hline Strain (Farms) & $\mathrm{LC}_{50(\%)}$ & Confidencelimit 95\% & $\mathrm{LC}_{99(\%)}$ & Confidence limit 95\% & RF \\
\hline Mozo* & 0.0123 & $0.0059-0.0193$ & 1.41 & $0.6997-4.5206$ & \\
\hline 1 & 0.317 & $0.1157-3.6938$ & 1.944 & $0.5909-25489.4$ & 25.7 \\
\hline 2 & 0.475 & $0.4104-0.5662$ & 2.432 & $1.6921-4.2215$ & 38.6 \\
\hline 3 & 0.425 & $0.2803-0.8336$ & 2.348 & $1.0759-23.6177$ & 34.5 \\
\hline 4 & 0.225 & $0.1199-0.5304$ & 1.552 & $0.6177-32.8560$ & 18.2 \\
\hline 5 & 0.452 & $0.1651-120.5383$ & 8.855 & $1.1657-3.2510$ & 36.7 \\
\hline 6 & 0.348 & $0.2427-0.5249$ & 1.423 & $0.8225-5.2731$ & 28.3 \\
\hline 7 & 0.268 & $0.0791-28.7434$ & 3.425 & $0.6446-1.8225$ & 21.8 \\
\hline 8 & 0.0058 & $0.0003-0.0145$ & 0.088 & $0.0434-0.4860$ & 0.5 \\
\hline 9 & 0.0339 & $0.0187-0.0527$ & 3.589 & $1.4549-16.7159$ & 2.7 \\
\hline 10 & $<0.0123$ & - & $<1.4$ & - & $<1$ \\
\hline 11 & 0.466 & $0.1375-2646.42$ & 30.451 & $2.1360-1.4522$ & 37.8 \\
\hline 12 & 0.15 & 7.026517E-02 - 0.5295205 & 3.11 & $0.7569834-212.1577$ & 12.2 \\
\hline
\end{tabular}

RF: Resistance Factor

*Reference sensitive strain

Table 3 - Values of lethal concentrations 50\% $\left(\mathrm{LC}_{50}\right)$ and $99 \%\left(\mathrm{LC}_{99}\right)$ and their respective $95 \%$ confidence limits for 12 Boophilus microplus population tested against the pyrethroid del tamethrin.

\begin{tabular}{|c|c|c|c|c|c|}
\hline Strain (Farms) & $\mathrm{LC}_{50(\%)}$ & Confidence limit 95\% & $\mathrm{LC}_{99(\%)}$ & Confidence limit 95\% & RF \\
\hline Mozo* & 0.00232 & $0.0007-0.0046$ & 0.78 & $0.4143-2.2923$ & \\
\hline 1 & 0.0256 & $0.0242-0.0526$ & 0.511 & $0.3436-0.8762$ & 11.0 \\
\hline 2 & 0.174 & $0.0610-0.6256$ & 1.341 & $0.4466-368.5854$ & 75 \\
\hline 3 & 0.156 & $0.0708-0.3829$ & 1.541 & $0.4006-1.0891$ & 67.2 \\
\hline 4 & 0.086 & $0.0507-0.1318$ & 0.721 & $0.3785-2.7836$ & 37.0 \\
\hline 5 & 0.271 & $0.1648-0.5460$ & 2.945 & $1.1277-32.7913$ & 116.8 \\
\hline 6 & 1.183 & $0.1595-0.2098$ & 0.653 & $0.5128-0.9289$ & 509.9 \\
\hline 7 & 0.0698 & $0.00059-1.3371$ & 0.344 & $0.0977-4.9163$ & 30.1 \\
\hline 8 & 0.00089 & $0.000043-0.002816$ & 0.108 & $0.0527-0.5502$ & 0.4 \\
\hline 9 & 0.0028 & $0.0008-0.0059$ & 0.707 & $0.3558-2.1847$ & 1.2 \\
\hline 10 & $<0.002$ & - & $<0,78$ & - & $<1$ \\
\hline 11 & 0.225 & $0.1197-0.3903$ & 2,160 & $0,9669-15,8392$ & 97.0 \\
\hline 12 & 0.0137 & $0.0049-0.0259$ & 0,3202 & $0,1240-3,2817$ & 6.0 \\
\hline
\end{tabular}

RF: Resistance Factor.

*Reference sensitive strain.

Table 4 - Values of lethal concentrations 50\% $\left(\mathrm{LC}_{50}\right)$ and $99 \%\left(\mathrm{LC}_{99}\right)$ and their respective $95 \%$ confidence limits for 12 Boophilus microplus populations tested against the organophosphorous compound chlorpyriphos.

\begin{tabular}{llllll}
\hline Strain (Farms) & $\mathrm{LC}_{50(\%)}$ & Confidencelimit 95\% & $\mathrm{LC}_{99(\%)}$ & Confidencelimit 95\% & $\mathrm{RF}$ \\
\hline Mozo* & 0.0141 & $0.0015-0.0222$ & 0.0311 & $0.0197-0.0724$ & \\
1 & 0.041 & $0.0327-0.0199$ & 0.724 & $0.4574-1.4114$ & 2.9 \\
2 & 0.0074 & $0.0051-0.0098$ & 0.534 & $0.3350-1.0399$ & 0.5 \\
3 & 0.084 & $0.0744-0.0969$ & 3.47 & $2.2098-6.1834$ & 5.9 \\
4 & 0.041 & $0.0325-0.0506$ & 13.02 & $5.1277-51.9154$ & 2.9 \\
5 & 0.039 & $0.0236-0.0594$ & 1.40 & $0.5403-10.7399$ & 2.7 \\
6 & 0.0096 & $0.0036-0.0166$ & 2.82 & $0.9894-21.8052$ & 0.7 \\
7 & 0.0126 & $0.0085-0.0166$ & 0.152 & $0.1000-0.3090$ & 0.8 \\
8 & 0.0125 & $0.0091-0.0155$ & 0.102 & $0.0740-0.1723$ & 0.9 \\
9 & 0.0077 & $0.00000073-0.0151$ & 0.0244 & $0.0100-0.3027$ & 0.5 \\
10 & 0.016 & $0.0122-0.0195$ & 0.076 & $0.0559-0.1299$ & 1.1 \\
11 & 0.042 & $0.0351-0.0513$ & 1.45 & $0.7938-3.4444$ & 3.0 \\
12 & 0.0031 & $0.00018-0.0083$ & 0.435 & $0.1728-6.2412$ & 0.2 \\
\hline
\end{tabular}

RF: Resistance Factor

*Reference sensitive strain. 


\section{DISCUSSION}

The results for cypermethrin (Table 2) are in accordancewith thefindings of MANGOLD etal. (2001) using A rgentinean strain (13.5); of VIEIRA-BRESSAN et al., (1999) using samples from Caçapava (12.29); of Mendes et al., (2001) for the M ancilha strain (8.68); of Mendes; VerísSImo (1999) for thestrains Lorena (9.82) and N ovaOdessa (8.89). Fragoso, etal.,(2004) reported that the M ora strain showed a resistancefactor equal to 118.7 , considered to be resistant level III according to the standard adopted in this study. Mendes \& Veríssimo (1999) classified sensitive strains in tick samples collected in Colina (1.27) and Mogi das Cruzes (1.02).

The results for deltamethrin aresimilar to results reported by BEUGNET; CHARDONNET (1995) and BIANCHI etal. (2003), who found RF classified as resistant level II and resistant level III in tick samples collected in New Caledonia farms. Tick population in farm 6 showed a RF equal to 509.9 (Table 3). Fragoso et al. (2004), in a similar study, found a RF to deltamethrin equal to 104 for Mora strain. These authors also reported the occurrence of strains resistant to deltamethrin with RF over 300 . Ticks resistant level II to deltamethrin werealso reported by VIEIRA-BRESSAN et al. (1999) and Mendes etal. (2001) with thesameRF (11) in samples collected in theValedo Paraíbaregion. Thesensitivity to del tamethrin observed in thisstudy shows that the RF is much greater for this acaricide than for cypermethrin. The high frequency of populations classified as sensitive (16.7\%) can possibly bedue to the fact that theuse of pyrethroids have been abandoned, altering thus the action mechanism related to changes in sodium channels. According to Foll et al. (2004) high resistance to pyrethroids can be obtained with just one site of mutation in sodiumchannels. Tickssensitivity profile to organophosphatescompoundscould beemerging. According to Fragoso et al. (2004), resistance to organophosphates compounds develops in approximately 7-8 years after their use. Most of the population analyzed wassensitiveto chlorpyriphos (Table4), similar to what was observed by MENDEs et al. (2001) for Mancilhastrain. Resistancelevel II strains observed in thisstudy showed similar characteristics to those of strains Tully, Ingham, Biarra and Mackay from Australia. The resistance to organophosphates compounds had been reported, in Brazil, by SHAw et al., 1968; Amaral et al. (1974) and Patarroyo; Costa (1980). Theseauthors had used thelarval immersion test.

Theabsenceof reportson theresistanceto amitraz may be due to the late development of methods to measureresistance, as well as theslow characteristic of this product in the development of resistance
(FraGoso etal., 2004). Resistanceto organophosphate had been reported since1963 (LeAL etal., 2003), when the use of pyrethroids and formamidines became popular. In thenineties, resistanceto pyrethroidsand amitraz was first reported (FAO, 2004), and from the year 2000 on, there were reports on the resistance to macrocyclic lactones (MARTINS; FURLong, 2001; Benavides; Romero, 2000). A return to the use of organophosphate and their associations may be observed, and the reemergence of resistance to these products for sure will occur.

Results regarding the acaricide methods application weresimilar to those obtained by RocHA (1995). The misuse of spray application leads to tick resistance(BIANCHI etal., 2003). Theuseof macrocyclic lactonesgenericcompoundsinjectablefortick control increased from $14.3 \%$ to $18.8 \%$ dueto affordableprices on cattlemarketThecombination between pyrethroids and organophosphates compounds increased from $23.8 \%$ to $43.7 \%$. The high frequency of tick samples classified assensitivemay beduetotheuseof amitraz that eliminated the tick population resistant to pyrethroids.

Based on theobtained dataanalerton good practices aimingtick control should berecommended in order to identify and monitor resistance, minimizing the use of acaricides as well as mistakes in the products choice.

References

Аввотт, W.S. A method of computing the effectiveness of an insecticide. Journal of Economic Entomology, v.18, p.256-257, 1925.

Amaral, N.K.; M onmany, L.F.S.; Carvalho,L.A.F.A caricide A C84633: first trial sfor control of Boophilusmicroplus. Journal of Economic Entomology, v.67, n.3, p.387-389, 1974.

BAXTER, G.D.; BARKER, S.C. I solation of CDN A anoctopaminelike, G-protein coupled receptor from the cattletick, Boophilus microplus. Insect Biochemistry and M olecular Biology, v.29, p.461-467, 1999.

Beugnet, F.; Chardonnet, L. Tick resistanceto pyrethroids in New Caledonia. V eterinary Parasitology, v.56, n.4, p.325-338, 1995.

Benavides, E.O.; Romero, A.N. Preliminary results of a larval resistance test to ivermectins using Boophilus microplus reference strains. A nnals of the $\mathrm{N}$ ew Y ork A cademy of Sciences, v.916, p.610-612, 2000.

BIANCHI, M.W.; BARRÉ, N.; M ESSAD, S. Factors related to cattle level resistance to acaricides in Boophilus microplus tick populations in $\mathrm{New}$ Caledonia. $\mathrm{V}$ eterinary Parasitology, v.112, n.1/ 2, p.75-89, 2003.

CRAMPTON ,A.I.;BAXTER, G.D.; BARKER, S.C. Identification and characterization of a cytochrome $\mathrm{P} 450$ gene and processed pseudogene from an arachinid: the cattle tick, Boophilus microplus. Insect Biochemical and M olecular Biology, v.29, p.377-384, 1999. 
DAveY, R.B.; George, J.E.. In vitroand in vivo evaluations of a strain of Boophilusmicroplus (A cari:Ixodidae) selected for resistance to permethrin. Journal of M edical Entomology, v.35, n.6, p.1013-1019, 1998.

FAO,. G uidel ines resistancemangement and interated parasite control in ruminants. Roma: FAO, 2004.

Fragoso, S.H.;M ARTINEZ, I.F.;Ortiz, N .A. Situación actual de la resistencia a los ixodicidas en México, 2004. p.1-8. Disponível em: $<$ http:/ web.andinet.com/ redectopar $>$. A cesso em: out. 2004.

Foil, L.D.; Coleman, P.; Eisler, M.; Fragoso-Snachez, H.; Garia-Vazquez, Z.; Guerrero, F.D.; Jonsson, N.N.; Langstaff, I.G.; L, A.Y.; Machila, N.; MilleR, R.J.; MORTON , J.; PRUETT, J.H.;TORR, S. Factorsthat influence thepreval ence of acaricideresistanceand tick-borne diseases. V eterinary. Parasitology, v.125, p.163-181, 2004.

Guerrero, F.D.; Davey, R.B.; Miller, R.J. Use of an allelespecificpolymerasechain reaction assay to genetype pyrethroid resistant strains of Boophilus microplus (Acari:Ixodidae). Journal of M edical Entomology, v.38, n.1, p.44-50, 2001.

Jamroz, R.C.; Guerrero, F.D.; Pruett, J.H.; Oehler, D.D.; MILLER, R.J. Molecular and biochemical survey of acaricide resistance mechanisms in larvae from M exican strains of the southern cattle tick, Boophilus microplus. Journal of Insect Physiology, v.46, n.5, p.685695, 2000.

Leal, A.T.;Freitas, D.R.J.;V azJunior, I.S. Perspectivas para o controle do carrapato bovino. Acta Scientiae V eterinariae, v.31, p.1-11, 2003.

Mangold,A.J.;M uñoz Cobeñas, M.E.;Casteli, M.;Scherling, N.J.; Delfino, M.R.; Gugliemone, A.A. Resistencia a cipermetrina en una población deBoophilusmicroplus (Acari:Ixodidae) del norte de Santa Fe, Argentina. A nuario 2000. 2001.

Martins, J.R.; Furlong, J. A vermectina resistance of the cattle tick Boophilus microplus in Brazil. Veterinary Record, v.149, n.92, p.64, 2001.

Mendes, M.C.;SILVA, M.X.;Bracco,J.E.Testebioquímico para determinar a resistência de duas cepas do carrapato Boophilus microplus (Canestrini,1887). R evista Brasileira de Parasitologia V eterinária, v.10, n.2, p.61-65, 2001.
Mendes, M.C.; Veríssimo, C.J. CarrapatoBoophilusmicroplus resistente ao piretróide cypermethrin. In: SEMINÁRIO BRASILEIRO DE PARASITOLOGIA VETERINÁRIA, 11,SEMINÁRIOBRASILEIRODEPARASITOLOGIA VETERINARIA DOS PAÍSES DO MERCOSUL, 2., SIMPÓSIO DE CONTROLE INTEGRADO DE PARASITOSDE BOVIN OS, 1., 1999, Salvador. A nais. Il héus: Universidade Estadual de Santa Cruz, 1999. p.73.

Miller-Robert, J.; Davey-Ronald, B.; George-John, E. Characterization of pyrethroid resistance and susceptibility to coumaphos in Mexican Boophilus microplus (Acari: Ixodidae). Journal of $M$ edical Entomology, v.36, n.5, p.533-538, 1999.

PatarRoyo,J.H.; C OSTA, J.O.Susceptibility of Brasilian samples of Boophilusmicroplus to organophosphorusacaricides. Tropical A nimal H ealth and Production, v.12, p.6-10, 1980.

RochA, C.M.B.M. Caracterização da percepção dos produtores do município de Divinópolis/M G sobre a importância do carrapato Boophilus microplus efatores determinantes das formas de combate utilizadas. 1995. 205p. Dissertação (mestrado) - Universidade Federal deMinas Gerais, Belo Horizonte, 1995.

Romero,A.Benavides,E.,H errera, C., Parra, M.H. Resistencia de la garrapata Boophilus microplus a acaricidas organofosforados y piretróides sintéticos em el departameento Del Huila Revista Colombiana de Entomologia, v. 23, n.1/ 2, p.9-17, 1997.

Stone , B.F.; HaYdock, K.P. A method for measuring the acaricidesusceptibility of thecattleB. microplus(Can.). Bulletin of Entomological R esearch, n.53, p.563-578, 1962.

SHaw, R.D.; COOCK, M.; CARSON, R.F. Developments in the resistance status of the southern cattle tick to organophosphorusand carbamateinsecticides.Journal of E conomic Entomology, v.61, p.1590-1594, 1968.

Vieira-Bressan, M.C.; Oiveira, R.O.; Sintos, A.P. dos Determination of $\mathrm{DL}_{50}$ and $\mathrm{DL}_{99}$ in two susceptible strains of Boophilus microplus for larval resistance tests. Revista Brasileira de Parasitologia V eterinária, v.8, n.2, p 119-126, 1999.

Received on 3/ 4/ 06 Accepted on 16/ 4/ 07 